\title{
ESTIMATING PARTICLE CONCENTRATION IN NATURAL WATER BY FAR FIELD SPECKLE INTENSITY
}

\author{
Dan CHICEA * and Liana-Maria CHICEA ** \\ * "Lucian Blaga" University of Sibiu, Faculty of Sciences, Dr. Ion Raţiu Street 5-7, Sibiu, Sibiu County, \\ Romania, RO-550012, dan.chicea@ulbsibiu.ro \\ ** "Lucian Blaga" University of Sibiu, Medicine Research Centre, Lucian Blaga Street 2A, Sibiu, Sibiu \\ County, Romania, RO-550169, liana.chicea@gmail.com
}

DOI: 10.2478/trser-2013-0017

KEYWORDS: Coherent light-scattering, aqueous suspension, particle concentration, speckle intensity.

\section{ABSTRACT}

A coherent light-scattering experiment on an aqueous clay suspension having a concentration that stretches over an extended range was carried on. The far field speckle was recorded in an unconventional manner.

A computer code for image processing, written for this purpose, was used to extract the scattered light intensity. The variation of the average scattered light intensity with the particle concentration was analyzed, and a possible fast procedure for assessing the particle concentration is suggested.

ZUSAMMENFASSUNG: Abschätzung der Partikelkonzentration in natürlichem Wasser durch Messung der Intensität des kohärenten zerstreuten Lichtes.

Die Arbeit stellt ein kohärentes Lichtstreuungsexperiment vor, das in einer wässerigen Schlammflüssigkeit, mit einer Konzentration, die sich über einen großen Aktionsradius erstreckt, durchgeführt wurde. Das Interferenzbild wurde auf unkonventionelle Art und Weise als Film aufgezeichnet.

Um die Streulichtintensität zu berechnen, wurde ein spezieller, eigens für dieses Experiment geschriebener PC Kode für Bildbearbeitung benutzt. Die Variation der Streulichtintensität in Abhängigkeit von der Partikelkonzentration wurde beobachtet und als Ergebnis ein rasches Verfahren zur Schätzung der Partikelkonzentration vorgeschlagen.

REZUMAT: Estimarea concentrației de particule în apa naturală prin măsurarea intensității luminii coerente împrăştiate.

A fost efectuat un experiment de împrăştiere a luminii pe suspensie de nămol având o concentraţie care se întinde pe mai multe ordine de mărime. Imaginea de interferenţă a fost înregistrată într-o manieră neconvenţională.

Intensitatea medie a luminii împrăştiate a fost extrasă din înregistrare folosind un program scris în acest scop. A fost analizată variaţia intensităţii medii cu concentraţia de particule. Ca rezultat este sugerat un procedeu rapid de estimare a concentraţiei. 


\section{INTRODUCTION}

Natural water contains particles in suspension, which causes water opacity. This physical property of natural water is named turbidity $(* * *, 2002)$. Suspended particles can be clay, sand, silt, algae, plankton, micro-organisms and other substances (***, 2006). Suspended particles absorb visible light and this causes the increase of the particle temperature. Heat is transferred to water; therefore temperature increases faster in turbid water than it does in clear water under the same incident light intensity. Gumpinger et al. (2010) stated that "water temperature is considered one of the most essential regulating parameters in aquatic ecosystems". Moreover, because of the intensive interrelations with other physical and chemical parameters, water temperature has a high indicative value when considering the general condition of a river ecosystem (Gumpinger et al., 2010).

Turbidity is often used as an indicator of the total amount of material suspended in water, but is neither a measure of the concentration nor of the size of the particles. Nevertheless, good knowledge of the size and the type of the suspended particles is important, because the fine particles suspended in water can carry bacteria, excess nutrients and toxic materials, which might be a hazard for water.

Optical procedures for assessing the amount of particles in suspension are appealing because they are fast to perform and do not require physical or chemical sample processing. When coherent light crosses a medium having scattering centers (SC), a non uniformly illuminated image is obtained, currently named speckled image, as explained in a report of previous work on this subject (Chicea, 2013 a, b). The image is not static but changes in time giving the aspect of "boiling speckles" (Goodman, 1984; Briers, 2001).

The speckled image can be observed either in free space, in which case it is named objective speckle (Goodman, 1984) or far field speckle (Briers, 2001), or on the image plane of a diffuse object, in which case it is named subjective speckle (Goodman, 1984) or image speckle (Briers, 2001). In this work, the objective speckle, respectively far field speckle is considered as in Chicea (2013 a, b).

The dynamics of the speckle field was analyzed by correlometric methods (Boas and Yodh, 1997; Aizu and Asakura, 1991; Fedosov and Tuchin, 2001) or by laser speckle contrast analysis (Briers et al., 1999; Zimnyakov et al., 2002). The speckle size can be used to measure the roughness of a surface (Lehmann, 1999; da Costa and Ferrari, 1997; Berlasso et al., 2000) or to assess the thickness of a semi-transparent thin slab (Sadhwani et al., 1996). Giglio et al. (2001) and other papers report on the near-field speckle dependence of the particles size. The work reported by Piederrière et al. (2004 a, b) and Chicea (2010) used a transmission optical set-up to measure the far field. This type of experimental setup is used in the work reported here, which is a continuation of the previous experimental work (Chicea, $2013 \mathrm{a}, \mathrm{b})$ but which uses a different procedure for data processing and for interpreting the results.

\section{MATERIAL AND METHODS}

The clay collected from the bottom riverbed of the Trinkbach River, that crosses Sibiu city, was diluted in water, allowed to sediment for 24 hours and the water was discarded to remove the organic suspension. The sediment was dried, weighed and then was mixed with deionised water to produce samples of clay particle suspension with different concentrations. 
Prior to starting the light-scattering image experiment, a diluted suspension was subject to a Dynamic Light-scattering experiment using a modified procedure extensively described in previous papers (Chicea, 2010; Chicea, 2012 a; Chicea et al., 2012). The average diameter of the clay particles was found to be $0.6 \mu \mathrm{m}$, as previously reported (Chicea, $2013 \mathrm{~b}$ ). The samples and the recordings are the same as in the previous work, but the data processing procedure is different, as presented further on. The scheme of the experiment and the detailed description of the experimental setup is presented in a previous article (Chicea, $2013 \mathrm{~b}$ ), in figure 1 together with a frame of a recording, in figure 2 of the same article (Chicea, $2013 \mathrm{~b}$ ); therefore they are not repeated here.

The average speckle size is calculated as the normalized autocovariance function of the intensity speckle pattern recorded in the observation plane (Piederrière et al., 2004 a, b). The average speckle contrast was analyzed in connection with the particle concentration and the results have already been presented (Chicea, 2013 b). In this paper an alternative approach is proposed to relate the particle concentration to the average scattered light intensity.

Unlike the work reported by Chicea (2012 b), where a punctual detector was used, a charged coupled device was used in this work and a video was recorded rather than a time series. A computer program was written to read the video recorded in a conventional format and to extract the level of the scattered light intensity. The program reads the video and extracts frame by frame in a 640 x 480 array of 24 bits intensity levels. We can note $I(i, j)=$ $\mathrm{I}(\mathrm{xi}, \mathrm{yj})$ the intensity recorded by the cell $(\mathrm{i}, \mathrm{j})$ of the CCD, hence by the pixel $(\mathrm{i}, \mathrm{j})$ of the array of pixels that make up the image. Once the array of intensities is extracted for each frame, the levels of intensity are averaged for that frame. The collection of intensity values is averaged for the whole recording and the average value I is considered to be the intensity value for that particular video, hence for that particular sample. The standard deviation for the collection of intensity values computed for one sample is considered to be the relative error in assessing the intensity for that particular sample; therefore the error bars in figure number 1 are the standard deviations.

A number of 22 samples having clay suspension with different concentrations were prepared. For each sample the cuvette was filled with the suspension and an MPEG type of video lasting for 30 seconds and containing 300 frames was recorded and processed as described above. The video was converted to an AVI format later on and processed as described above.

A simple physical procedure was also used to measure the actual amount of sediment in a sample, as an alternative and control method, although tremendously more time consuming. It consists of weighing an empty and freshly cleaned Petri dish, adding $50 \mathrm{ml}$ of suspension in the dish and allowing it to slowly evaporate at a temperature around $60^{\circ} \mathrm{C}$ that was controlled by adjusting the distance from the dish to a pair of $100 \mathrm{~W}$ light bulbs. In the work previously reported (Chicea, $2013 \mathrm{~b}$ ), there was only one light bulb that was used as a heat source while for this work we used a pair of bulbs to increase the temperature. Moreover, the temperature was risen to $60^{\circ} \mathrm{C}$ and this decreased the time to dry the sample. We did not pass $60^{\circ} \mathrm{C}$ as there is the risk to produce fast evaporation during the temperature adjustment procedure and this might evacuate the very small particles and produce a systematic error in weighing the amount of dry clay. After the water evaporation was completed, the dish with the sediment was weighed again and the difference represented the sediment mass. More details on this method and on assessing the relative error of the method are presented in the previous paper on this subject (Chicea, $2013 \mathrm{~b}$ ). 


\section{RESULTS AND DISCUSSION}

The samples were prepared using the procedure described in the previous section starting with a concentration of $7.5 \mathrm{~g} / \mathrm{l}$ and decreasing it by successive dilution down to 0.081 $\mathrm{g} / \mathrm{l}$. This concentration range is quite extended, as it covers two orders of magnitude. The average scattered light intensity was computed for each sample and the average scattered light intensity versus clay concentration is presented in figure number 1.

We notice that in figure number 1 the average intensity, I, exhibits an increasing trend in the very small concentration range, up to $0.35 \mathrm{~g} / \mathrm{l}$. From $0.35 \mathrm{~g} / \mathrm{l}$ up to $6.67 \mathrm{~g} / \mathrm{l}$ the average intensity decreases monotonously. As the concentration increases above $6.67 \mathrm{~g} / \mathrm{l}$ the average intensity exhibits an increasing trend again. Overall, the curve that can be plot through the data points is smooth and the error bars are small relative to the range of average intensity values.

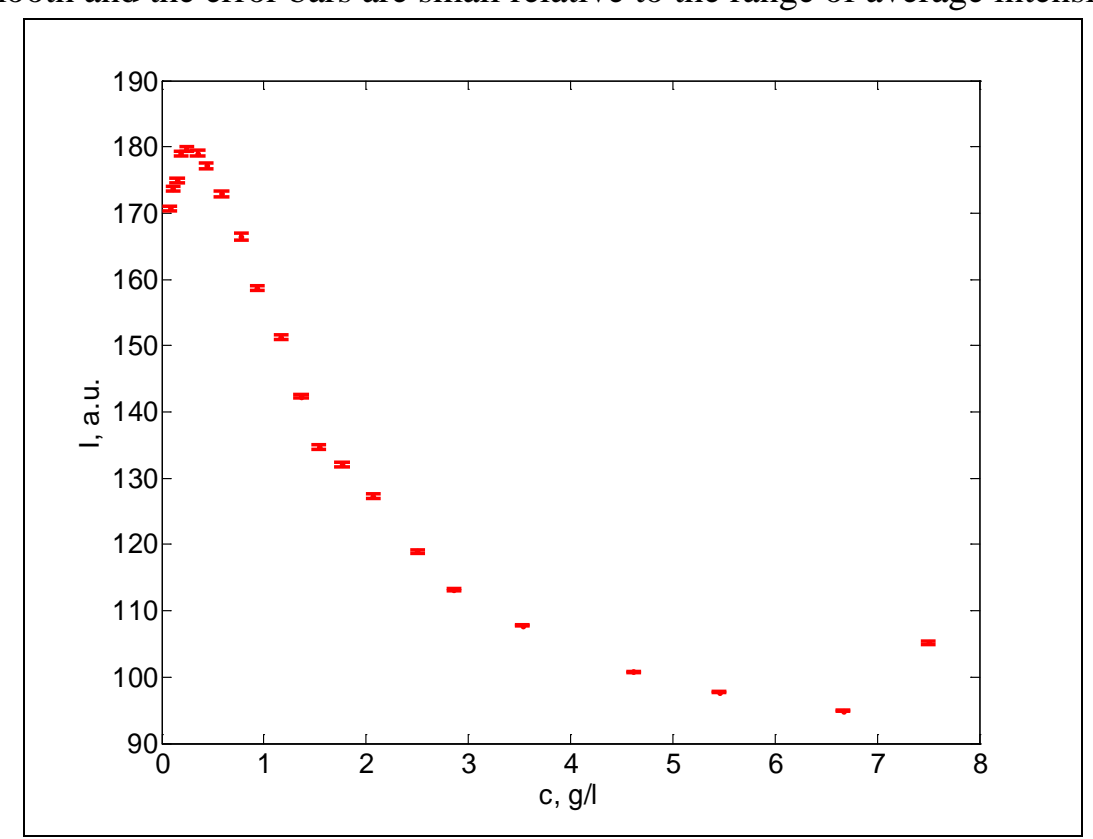

Figure 1: The average scattered light intensity versus clay concentration (c); intensity is expressed in arbitrary units (a.u.) and concentration in grams per litre (g/l).

This result is similar to the results reported by Piederrière et al. (2004 a) on latex microspheres, although at a first look Piederrière et al. (2004 a) presents an almost linear decrease. This can be explained by the much bigger concentration range used in this work. The work presented in Piederrière et al. (2004 a) represents just a small area of the extended decreasing part of the curve in figure number 1. Examining the plot of average intensity by concentration we notice that the monotone interval can be used as a calibration curve for measuring the concentration in the $0.35-6.67 \mathrm{~g} / \mathrm{l}$ concentration range.

The procedure was tested on four samples obtained by mixing two unmeasured volumes of different diluted samples, therefore the clay concentration being unknown, following the procedure presented in Chicea (2013 b). The samples were analyzed both by using the curve in figure number 1 as a calibration and by evaporation followed by weigh difference. The results are presented in table number 1 , where the first column is the clay concentration measured by the sediment mass, after evaporation, divided by the $50 \mathrm{ml}$ volume; the second column contains the concentration measured by average intensity assessment; the third column contains the error of one method relative to the other, considering the weigh method as reference; and the fourth column contains the error of the weight difference method. 
The slope of the curve in figure number 1 in the monotone range is bigger in the smaller clay concentration range, which makes the average intensity method more precise in this range, where the weight difference method has a lower precision, as explained in detail in a previous paper (Chicea, $2012 \mathrm{~b}$ ) and proved by the fourth column in table number 1 .

The procedure described in the material and method section resembles to a certain degree the physical procedure previously described (Chicea, 2012 b), yet it is essentially different. In this work image recording using a webcam and a computer followed by image processing is used, while the work previously reported was carried on using a detector, a data acquisition system, a computer, and it required time series processing.

Table 1: The concentration of four unknown samples and the errors in measuring the concentrations.

\begin{tabular}{|c|c|c|c|}
\hline $\begin{array}{c}\text { Concentration g/l } \\
\text { (weight difference) }\end{array}$ & $\begin{array}{c}\text { Concentration g/l } \\
(<\mathrm{I}>\text { ) }\end{array}$ & $\begin{array}{c}\text { Error between } \\
\text { methods (\%) }\end{array}$ & $\begin{array}{c}\text { Error in weight } \\
\text { difference (\%) }\end{array}$ \\
\hline 0.38 & 0.39 & 2.56 & 10.5 \\
\hline 0.76 & 0.79 & 3.8 & 5.2 \\
\hline 2.5 & 2.36 & 5.93 & 1.6 \\
\hline 5.1 & 5.6 & 8.93 & 0.8 \\
\hline
\end{tabular}

\section{CONCLUSIONS}

A simple physical procedure using the far interference field of a coherent light beam incident on a suspension can be used to assess the clay concentration in natural water over a concentration range that covers more than one order of magnitude. The average scattered light intensity is extracted and computed using a program written for this purpose. The average intensity variation with the clay concentration was found to be monotone over an extended concentration range, specifically from $0.35 \mathrm{~g} / \mathrm{l}$ to $6.67 \mathrm{~g} / \mathrm{l}$. This is a range with a relatively big concentration in natural water, as the water sample is opaque even for a $12 \mathrm{~mm}$ thick cuvette. For such a big concentration turbidity is not measurable with the simple method using the Secchi disk (***, 2002). The monotone part of the plot in figure number 1 can be used as a calibration curve. An unknown sample can be used as a target for the laser beam and a video can be recorded, the average intensity can be measured using the above mentioned procedure and the monotone part of the plot in figure number 1 can be used to assess the clay concentration in that water sample.

The method proposed in this article is very fast, as it does not require chemical or physical sample processing, but simply putting the sample in a cuvette, recording and processing the video. Once the average scattered intensity is computed, finding the concentration from the plot in figure number 1 is straightforward. A refinement might consist in fitting a polynomial on the monotone part of the plot in figure number 1 , considering the concentration versus intensity and using the polynomial for a direct calculation of the concentration from the computed average intensity. The above mentioned steps take less than ten minutes, once the calibration curve is ready to be used. Caution should be taken and a preliminary concentration assessment by sedimentation, evaporation and weighing the sediment should be performed, in order to make sure that the concentration is in the monotone range of figure number 1 . A faster, but empirical procedure to make sure of this is to simply look at the $12 \mathrm{~mm}$ thick cuvette filled with the sample; this should not look completely transparent, like deionised water, because in this case the concentration is below the starting part of the monotone portion of the plot, that is below $0.35 \mathrm{~g} / \mathrm{l}$. 


\section{ACKNOWLEDGMENTS}

Many thanks to the environmental sciences group of the Faculty of Sciences at the "Lucian Blaga” University of Sibiu for fruitful discussions and for clarifying certain issues related to physical factors involved in environment protection. I am also deeply indebted to the Transylvanian Review of Systematical and Ecological Research editors, Curtean-Bănăduc A. and Bănăduc D., for their continuous support and encouragement to carry on experimental work related to environment assessment and monitoring. 


\section{REFERENCES}

1. Aizu Y. and Asakura T., 1991 - Bio-speckle phenomena and their application to the evaluation of blood flow, Optical Laser Technology, 23, 205-219.

2. Berlasso R., Perez F., Rebollo M. A., Raffo C. A. and Gaggioli N. G., 2000 - Study of speckle size of light scattered from cylindrical rough surfaces, Applied Optics, 39, 5811-5819.

3. Boas D. A. and Yodh A. G., 1997 - Spatially varying dynamical properties of turbid media probed with diffusing temporal light correlation, Journal of the Optical Society of America, 14, 192-215.

4. Briers J. D., Richards G. and He X. W., 1999 - Capillary blood flow monitoring using laser speckle contrast analysis (LASCA), Journal of Biomedical Optics, 4, 164-175.

5. $\quad$ Briers J. D., 2001 - Laser Doppler, Speckle and related techniques for blood perfusion mapping and imaging, Physiological Measurement, 22, R35-R66.

6. da Costa G. and Ferrari J., 1997 - Anisotropic speckle patterns in the light scattered by rough cylindrical surfaces, Applied Optics, 36, 5231-5237.

7. Chicea D., 2010 - Nanoparticles and Nanoparticle Aggregates Sizing by DLS and AFM, Journal of Optoelectronics and Advanced Materials, 4, 9, 1310-1315.

8. Chicea D., 2012 a - A Study of Nanoparticle Aggregation by Coherent Light-scattering, Current Nanoscience, 8, 6, 259-265.

9. Chicea D., 2012 b - A Coherent Light-scattering Procedure to Measure Very Small Concentration of Organic Suspension in Natural Water, Transylvanian Review of Systematical and Ecological Research, Curtean-Bănăduc A. et al. (eds), 14, 1-8.

10. Chicea D., Indrea E. and Crețu C. M., 2012 - Assessing $\mathrm{Fe}_{3} \mathrm{O}_{4}$ Nanoparticle Size by DLS, XRD and AFM, Journal of Optoelectronics and Advanced Materials, 14, 5-6, 460-466.

11. Chicea D., 2013 a - Estimating Particle Concentration in Natural Water by Speckle Size Measurement, Proceedings of 11th International Conference on Environment, Ecosystems and Development, Braşov, Romania, June 1-3, 151-161.

12. Chicea D., 2013 b - Estimating Particle Concentration in Natural Water by Speckle Contrast, Transylvanian Review of Systematical and Ecological Research, Curtean-Bănăduc A. and Bănăduc D., (eds), 15.1, 1-10.

13. Fedosov I. V. and Tuchin V. V., 2001 - The use of dynamic speckle field space time correlation function estimates for the direction and velocity determination of blood flow, Proceedings of SPIE, 4434, 192-196.

14. Giglio M., Carpineti M., Vailati A. and Brogioli D., 2001 - Near-field intensity correlation of scattered light, Applied Optics, 40, 4036-4040.

15. Goodman J. W., 1984 - Statistical Properties of Laser Speckle Patterns, in Laser speckle and related phenomena, 9 in series Topics in Applied Physics, J. C. Dainty, Edit. Springer-Verlag, Berlin, Heidelberg, New York, Tokyo, 9-75.

16. Gumpinger C., Höfler S., Berg K. and Scheder C., 2010 - Water temperature as an applicable parameter with a high indicative value for the general condition of a river-ecosystem, drawing on the example of the river Trattnach in Upper Austria, Transylvanian Review of Systematical and Ecological Research, Curtean-Bănăduc A. et al. (eds), 10, 1-14.

17. Lehmann P., 1999 - Surface-roughness measurement based on the intensity correlation function of scattered light under speckle-pattern illumination, Applied Optics, 38, 1144-1152.

18. Piederrière Y., Le Meur J., Cariou J., Abgrall J. F. and Blouch M. T., 2004 a - Particle aggregation monitoring by speckle size measurement, application to blood platelets aggregation, Optics Express, 12, 4596-4601.

19. Piederrière Y., Cariou J., Guern Y., Le Jeune B., Le Brun G. and Lotrian J., 2004 b - Scattering through fluids: speckle size measurement and Monte Carlo simulations close to and into the multiple scattering, Optics Express, 12, 176-188. 
20. Sadhwani A., Schomaker K. T., Tearney G. J. and Nishioka N. S., 1996 - Determination of Teflon thickness with laser speckle. I. Potential for burn depth diagnosis, Applied Optics, 35, 5727-5735.

21. Zimnyakov D. A., Briers J. D. and Tuchin V. V., 2002 - Speckle technologies for monitoring and imaging of tissues and tissue like phantoms, chapter 18, in Handbook of biomedical diagnostics, Valery V. Tuchin, Edit. SPIE, Bellingham, 987-1036.

22. ***, 2002 - Waterwatch Australia National Technical Manual, Module 4, July - Waterwatch Australia Steering Committee, Environment Australia, ISBN 0-6425-4856-0, 19-21.

23. ***, 2006 - National Soil Survey Handbook Part 618 Soil Properties and Qualities, United States Department of Agriculture - Natural Resource Conservation Service, as of May, 42-55. 